\title{
“ THE NATURE, DETERMINATION, AND CLINICAL IMPORTANCE OF BLOOD IODINE: A REVIEW
}

\author{
BY \\ J. D. ACLAND \\ From the Department of Pharmacology and Therapeutics, University of Sheffield and \\ Sheffield Royal Infirmary
}

(RECEIVED FOR PUBLICATION NOVEMBER 12, 1957)

\section{Normal and Abnormal Constituents of Blood Iodine}

In normal conditions, serum (or plasma) iodine is largely composed of thyroxine and iodide with small quantities of thyroactive iodothyronines, such as $3: 5: 3^{\prime}$-tri-iodothyronine and $3: 3^{\prime}$-di-iodothyronine (Gross and Pitt-Rivers, 1952; Roche, Lissitzky, and Michel, 1952a and b; Roche, Michel, Nunez, and Wolf, 1956). Another relatively less active compound, $3: 3^{\prime}: 5^{\prime}$-tri-iodothyronine, is present in thyroid gland hydrolysates (Roche et al., 1955) and may be present in plasma in quantities too small to detect, since it is not broken down by the thyroid (Roche et al., 1956).

Mono- and di-iodotyrosine, known to be present in thyroid hydrolysates (Harington and Randall, 1929 ; Fink, Dent, and Fink, 1947), are not found in normal sera, being deiodinated by an enzyme present in the thyroid gland (Roche, Michel, Michel, and Lissitzky, 1952). In certain types of familial goitre, however, mono- and di-iodotyrosine are present in serum as a result of the absence of the thyroid deiodinating enzyme (Stanbury, Kassenaar, Meijer, and Terpstra, 1955 ; Querido, Stanbury, Kassenaar, and Meijer, 1956 ; Stanbury, Meijer, and Kassenaar, 1956).

Thyroxine and, to a lesser extent, $3: 5: 3^{\prime}$-triiodothyronine have been shown to be bound to a specific plasma protein, intermediate in properties between $\alpha_{1}$ and $\alpha_{2}$ globulins (Trevorrow, 1939 ; Taurog and Chaikoff, 1948; Gordon, Gross, O'Connor, and Pitt-Rivers, 1952 ; Deiss, Albright, and Larson, 1953 ; Petermann, Robbins, and Hamilton, 1954 ; Robbins, Petermann, and Rall, 1955). No data are available for mono-iodotyrosine or for other iodothyronines. The iodine fraction, which is precipitated with protein, mainly consists of thyroid hormone and is termed "protein-bound iodine (P.B.I.)."

Red cells normally contain iodide but no iodinated amino-acids (Joliot, Courrier, Horeau, and
Süe, 1944 ; Ingbar, Freinkel, Hoeprich, and Athens, 1954; Tata, 1954, quoted by Michel, 1956). However, red cell stroma adsorbs $3: 5: 3^{\prime}$ tri-iodothyronine (Hamolsky, 1955 ; Crispell, Kahana, and Hyer, 1956 ; Crispell and Coleman, 1956), so small amounts of this amino-acid might be found in erythrocytes if its plasma concentration was high.

Iodine-containing proteins may sometimes be detected in serum. Thyroglobulin is liberated into the blood as a result of thyroid surgery (Lerman, 1940) and 48 hours after the destruction of the thyroid by radio-iodine (Feller, Chaikoff, Taurog, and Jones, 1949 ; Tong, Taurog, and Chaikoff, 1952 ; Robbins, 1954; Robbins et al., 1954). Dobyns and Hirsch (1956) found that a substance, subsequently identified as thyroglobulin by isoelectric precipitation, electrophoresis, and ultracentrifugation (Dobyns, personal communication, 1956), was secreted into the cervical lymphatics of dogs in response to thyrotropic hormone. The dogs were given $1.4-3 \mathrm{mc}$. of ${ }^{131} \mathrm{I}$, thus enabling the labelled thyroglobulin to be detected. Most of the experiments were performed within 24 hours of administering ${ }^{131} \mathrm{I}$, but the fact that little or no thyroglobulin was present in the cervical lymph before giving thyrotropic hormone makes it unlikely that radiation damage to the thyroid was in any way responsible for their results. Other types of iodine-containing protein have been found in some samples of sheep and calf blood (Taurog, Wheat, and Chaikoff, 1956) and in the sera of patients suffering from carcinoma of the thyroid treated with large doses of iodine, the latter proteins resembling albumin (Larson, Deiss, and Albright, 1954 ; Robbins, Rall, and Rawson, 1955 ; Dingledine, Pitt-Rivers, and Stanbury, 1955 ; Tata, Rall, and Rawson, 1956).

\section{Determination of Blood Iodine}

Since plasma contains all, or nearly all, the blood hormonal iodine in loose combination with 
protein, a method of estimating the concentration of P.B.I. in plasma (or serum) would provide a measure of the amount of circulating thyroid hormone.

Such determinations are not very specific, since thyroxine can probably not be distinguished from other iodothyronines, although full data are not yet available. Iodine present in serum as thyroglobulin or in an abnormal serum albumin component would also be estimated as P.B.I., though it is not yet certain how accurately the iodine content of these proteins would be estimated by ordinary methods of P.B.I. determination. A number of artefacts may also interfere with the determination, as described later in connexion with the interpretation of individual analyses.

Methods of estimating iodine in organic combination can be classified into two main groups. In the first group incineration with alkali is used to destroy organic material, inorganic iodide being eluted from the resulting ash, while in the second group organic material is ashed by acid oxidizing agents, such as chromic and perchloric acids, or permanganate, in solution. The iodate so formed is then reduced to iodide and separated from the reaction mixture by distillation. In each case the inorganic iodide is usually estimated by the catalytic method originally described by Sandell and Kolthoff (1937), but some workers use a volumetric method (e.g., Riggs and Man, 1940).

The determination of serum inorganic iodide has not been used to a great extent in the assessment of thyroid function, because, although iodide is a normal blood constituent, its concentration is affected by the iodide intake.

Acid Distillation Methods.-The great technical problem in acid distillation methods is the distillation process itself. If a method of this type is to be of any practical use submicrogram quantities of iodine must be distilled from the digestion fluid and collected without loss, or at any rate with a constant loss. This has necessitated the construction of complicated, specially designed stills (Chaney, 1940; Taurog and Chaikoff, 1946; Barker, 1948). Attempts, such as that of Sobel and Sapsin (1952), to simplify the apparatus usually result in less reliable results. The method of Chaney (1940) gives satisfactorily reproducible results according to Sobel and Sapsin (1952) and Blackburn and Power (1955), but Chaney himself reported a recovery of only $84 \%$ when the sample contained $0.05 \mu \mathrm{g}$. of iodine, while $93 \%$ and $100 \%$ recoveries respectively were obtained with samples containing $0.5 \mu \mathrm{g}$. and $50 \mu \mathrm{g}$. of iodine. The methods of Taurog and Chaikoff (1946) and
Barker (1948) are subject to losses of 10 to $15 \%$ during the distillation, while acid distillation methods, other than that of Chaney (1940), do not give very satisfactory results (see Table I). Since

TABLE I

RELIABILITY OF SOME PUBLISHED METHODS OF DETERMINING SERUM PROTEIN-BOUND IODINE (Acland, 1957, with additional data)



* Calculated from the $95 \%$ range for the mean of duplicate estimations as given by the authors ( $\pm 5.6 \%$ and $\pm 10.9 \%$ respectively). + Calculated from the standard error for the mean of a duplicate 3 as given by the authors $( \pm 0.56)$.

\pm Calculated from the coefficient of variation for the mean of triplicate determinations as given by the authors $( \pm 3 \cdot 3 \%)$.

each distillation requires individual supervision, 음 the number of simultaneous determinations which $>$ can be carried out is limited. The use of specially․ㅡ. constructed glass apparatus is also a disadvantage.N This explains why acid distillation methods have not usually been found suitable for use in a routine laboratory.

Methods have been described which use acido digestion to convert organically bound iodine teo an inorganic form but omit the distillation step e.g., that of O'Neal and Simms (1953). Iodate? is determined directly on the diluted digest. 0 Although such techniques are simple to use (Reals? Townsend, and Danielson, 1956), the digestion

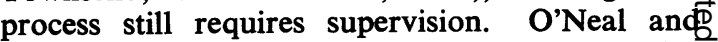
Simms (1953) obtained variable results from dayb to day and recommended the construction of new calibration curves with each batch of determinas 
tions. The standard deviation of duplicate analyses from their mean was $0.33 \mu \mathrm{g} . / 100 \mathrm{ml}$. The reproducibility attained is thus comparable to that of acid distillation methods as a whole, but is not as good as that of the best techniques, whether based on acid distillation or on alkaline ashing (see Table I).

Critical Examination of Alkaline Ashing Methods.-There are four stages in the estimation of serum P.B.I. by alkaline incineration: (1) Precipitation of serum proteins, (2) ashing, (3) elution of iodide from the ash, and (4) estimation of the released iodide.

In the protein precipitation stage, errors may arise both from incomplete precipitation of P.B.I. and from co-precipitation with protein of iodinecontaining compounds such as di-iodotyrosine, which do not normally form part of the P.B.I. According to Tong et al. (1954), only $90 \%$ of ${ }^{131}$ I-labelled thyroxine added to serum is recovered in a zinc hydroxide precipitate, while $95 \%$ is recovered in a trichloroacetic acid precipitate. No data are available for monoiodotyrosine. Subsequent investigators have concluded, however, that losses in this stage of the analysis should not be more than $5 \%$ with zinc hydroxide, provided that the concentration of zinc is adequate (Skanse and Hedenskog, 1955 ; Acland, 1957). It may be that the high concentration of thyroxine $(10-20 \mu \mathrm{g}$. $/ \mathrm{ml}$.) used by Tong et al. (1954) overloaded the thyroxine-binding mechanism.

Appreciable amounts of inorganic iodide (2-3\%) may remain in a washed trichloroacetic acid precipitate (Taurog et al., 1956), perhaps owing to the iodination of unsaturated lipids. In the case of zinc hydroxide precipitates also, therapy with potassium iodide, resulting in raised serum iodide levels, may give rise to spuriously high analytical results. Slade (1956) used a column of ion-exchange resin to separate inorganic from organic iodine in plasma. The plasma sample is run through the column, which retains the inorganic iodide, while the effluent contains the organic iodine. This method, while valuable for radio-iodine studies, is not a substitute for protein precipitation in chemical determinations, since the resin column was found to be a source of iodine contamination. Resin column purification is not worth while adopting as a routine in P.B.I. determinations, but it may be a useful alternative to repeated washing of the protein precipitate if the plasma inorganic iodide concentration is very high.
Losses of iodine may occur during ashing unless the temperature is kept below $620^{\circ}$ (Acland, 1957). Inconsistent results have been obtained when trichloroacetic acid precipitates are ashed below $650^{\circ}$ whereas above this temperature recoveries become low (Acland, 1957).

Grossmann and Grossmann (1955) drew attention to the possibility of losses in acid solution due to the conversion of iodide to iodine at the elution stage. The eluents used by Barker, Humphrey, and Soley (1951) and Brown, Reingold, and Samson (1953) have been found to give low recoveries (Acland, 1957) and the same results would be expected whenever elution takes place in acid conditions. The amount of acid added to the ash in the procedure recommended by Grossmann and Grossmann (1955) is enough to break up the residue but not enough to make the resultant suspension acid, and these authors' elution technique was found to give satisfactory results (Acland, 1957). Adsorption on the carbonized residue probably accounts for the losses of iodine occurring with acid eluents, since acidification after separation of the supernatant from the residue, as in the method of Grossmann and Grossmann (1955), does not result in a low recovery (Acland, 1957).

The estimation of iodide by its catalytic effect on the reaction between ceric salts and arsenious acid (Sandell and Kolthoff, 1937) depends upon the fact that the reduction of the ceric ion is normally a first order reaction, the rate-limiting process being the reaction between ceric ions and iodide (Glasstone, 1948). By a kinetic approach similar to that of Caraway (1952) it has been shown (Acland, 1957) that in the conditions of the analysis a linear relation should theoretically exist between the logarithm of the concentration of unchanged ceric ion and the amount of iodide present. Provided that ceric salts obey Beer's law, a straight line calibration curve should result if extinction is plotted against iodide concentration on semilogarithmic graph paper. Ceric salts in solution obey Beer's law only if the spectrophotometer used has an adequate monochromator, giving a performance equal to that of the Beckmann DU (Thompson, Klugerman, and Truemper, 1956) or of the "unicam" SP600 (Acland, 1957). With satisfactory instrumentation, a theoretical straight line calibration curve can be obtained (Acland, 1957) in the presence of chloride and sulphate, the former of which enhances the catalytic effect of iodide (Barker, 1948) while the latter retards it (Klein, 1954). 
Several workers (e.g., Grossmann and Grossmann, 1955 ; Meyer, Dickenman, White, and Zak, 1955 ; Fischl, 1956) have reported methods of poisoning the ceric sulphate-arsenious acid reaction, so that photometer readings may be made at any time after the reaction has stopped. This technique is claimed to be more accurate than that whereby readings are made at a fixed time after starting the reaction, while the optical density is still decreasing. On the face of it, this appears an attractive procedure. However, the colour obtained is not always stable, although Fischl (1956) claims that in the case of the brucine acetate-cerium complex full intensity can be developed by heating to $95-100^{\circ}$ for $5 \mathrm{~min}$. Usually there is no difficulty in timing the extinction reading to within 1 or $2 \mathrm{sec}$. and constancy of delivery time can be ensured by using the same pipette throughout to deliver the ceric ammonium sulphate solution (Acland, 1957).

Ultramicromethods. - In the case of most methods of P.B.I. determination, a venepuncture is necessary, since $0.5-1.0 \mathrm{ml}$. samples of serum are required. Fischl (1956), however, has described a technique which uses only $0.02-0.1 \mathrm{ml}$. of serum and would therefore be suitable for finger-prick blood. The necessary increase in sensitivity was claimed to result from the use of brucine acetate to stop the reaction between ceric and arsenite ions. The colour of the brucine acetate-cerium complex is much more intense than that of the ceric ion. In comparison with other methods, therefore, the light absorption can be measured at a higher wavelength $(540 \mathrm{~m} \mu$ instead of about $420 \mathrm{~m} \mu$ ), while the slope of the calibration curve relating optical density to iodide concentration is much steeper. Fischl (1956) claims that an increased accuracy results from the greater sensitivity. This claim applies, of course, only to spectrophotometric errors in the determination of ceric ion concentration. Errors due to contamination of the reagents with iodide remain proportionately the same, except in the case of the ceric ammonium sulphate and arsenious acid solutions, where they are about five times greater. The relative effect of pipetting errors involving the ceric ammonium sulphate solution is also increased five times. Errors in the digestion (or incineration) stage will not be affected, except possibly adversely, as a result of the smaller quantities of starting material. Fischl (1956) plots photometer readings (in logarithmic units) against iodine concentration to obtain a straight line calibration curve. As stated previously, this procedure has no theoretical justifica- tion since a straight line relation should exist between the logarithm of the optical density and the iodide concentration. It is possible that the use of a Klett-Summerson filter photometer may have prevented the brucine acetate-cerium complex from obeying Beer's law, since Thompson et al. (1956) were unable to obtain satisfactory results from this instrument with ceric salts in the absence of brucine.

Fischl (1956) has adapted his method both to a chloric acid digestion without distillation, similar to that of O'Neal and Simms (1953), and to an alkaline ashing technique, each resulting in different calibration curves. The acid digestion gives a higher blank and apparently a wider variation between duplicates, while alkaline ashing gives a steeper fall of optical density as the iodine concentration rises. However, the ashing was carried out at $650^{\circ}$, although only for 12 to $16 \mathrm{~min}$., and the ash was acidified with sulphuric acid, so losses of iodine are very likely to occur for the reasons already given.

Fischl (1956) quotes a " $1.5-3.0 \%$ deviation," obtained with triplicate determinations on samples of serum from hypothyroid, euthyroid, and hyperthyroid patients. A "range of error" of 5 to $8 \%$ was observed using smaller quantities of serum and reagents in a Klett micro tube. No figures are given for the recovery of thyroxine, either alone or added to serum.

Another attempt to develop an ultramicrotechnique has been reported by Sanz, Brechbühler, and Green (1956). They followed in most respects the procedure of Barker et al. (1951), scaled down to correspond to a serum sample of $0.05 \mathrm{ml}$. How ever, a Beckmann DU spectrophotometer was used and the light absorption of the ceric ion was measured at its absorption maximum, $317 \mathrm{~m} \mu$ instead of at the higher wavelengths normally used. As a result, while the concentration of iodide in the final reaction mixture remained the same as in the macro method, that of the ceric ion was reduced ten times. It seems very likely that in these conditions the concentration of the ceric ion would be too small for its reduction to follow first-order kinetics. Failure of this relation to hold at high iodide and low ceric ion concentrations has been observed (Thompson et a!., 1956; Acland, 1957). Sanz et al. (1956) observed that the transmittance at $317 \mathrm{~m} \mu$ showed a linear relation both with the reaction time and with the iodide concentration. Theoretically, the logarithm of the extinction and not the transmittance should show a linear relation with the last two variables (Barker et al., 1951; 
Acland, 1957). It is possible that the failure of the reaction in the experimental conditions to follow first order kinetics was compensated purely fortuitously by what is in effect a double antilog transformation.

Sanz et al. (1956) claim a precision of better than $\pm 1 \%$ and report a mean recovery of $99.7 \%$ for thyroxine added to seven serum samples. They determined serum P.B.I. concentrations in 12 normal subjects and found them to lie between 3.52 and $5.59 \mu \mathrm{g} . / 100 \mathrm{ml}$. (mean, 4.81). They comment that in Swiss subjects P.B.I. values are low owing to the lack of iodine in the water, but they do not report any clinical or other evidence relating to the thyroid function of their subjects. Protein-bound iodine determination by the alkaline incineration method of Barker et al. (1951) has been found to be subject to variable losses, probably during the iodide elevation stage after ashing (Brown et al., 1953 ; Acland, 1957). Conversion to the ultramicro scale would normally be expected to enhance rather than eliminate such losses. Sanz et al. (1956) also claim good agreement between the results of their technique and those of the unmodified Barker method when applied to the same serum specimen.

Further confirmatory work appears to be necessary before pronouncing judgment on these ultramicromethods for P.B.I. determination.

Conclusion.-As shown by the representative data quoted in Table $I$, alkaline incineration methods are capable of giving more reproducible results than acid distillation methods. Acland: (1957) reported a mean recovery of thyroxine added to serum of $93 \%$ (range $89-97 \%$ ) using an alkaline incineration method. Acid distillation methods usually have recoveries in the range 8590\% (Taurog and Chaikoff, 1946 ; Barker, 1948 ; van $\mathrm{Zyl}, 1953)$. Alkaline incineration methods cannot, however, be used satisfactorily unless there is a large excess of protein in the starting material (Acland, 1957). Van Zyl (1953) claims, on the other hand, that acid distillation methods enable small quantities of inorganic and organic iodide to be determined accurately in starting materials containing little protein, the important factor being a careful control of the concentration of the reagents used. Another disadvantage of alkaline ashing methods is that trichloroacetic acid precipitation gives inconsistent results when combined with this technique (Acland, 1957). Trichloroacetic acid precipitation can, however, be used satisfactorily in conjunction with acid distillation methods (Sobel and Sapsin, 1952). It would obviously be preferable to use trichloroacetic acid if possible in view of the co-precipitation with the P.B.I. of physiologically inactive substances, such as di-iodotyrosine, when zinc hydroxide reagents are used.

\section{The Chemical Fractionation of Serum Iodine}

The suggestion has often been put forward (e.g., Blomfield, Jones, Macgregor, Miller, and Wayne, 1951 ; Starr and Liebhold-Schueck, 1953) that different dysthyroid states might be characterized not only by quantitative changes in the amount of thyroactive substances secreted by the thyroid, but also by changes in its composition. Both the production by the thyroid of abnormal compounds and an alteration in the relative proportions of its normal secretory products have been postulated. It has consequently appeared important to many investigators to develop fractionation methods which would enable each component of serum iodine to be estimated separately.

The $n$-butanol extraction methods of Leland and Foster (1932) and Blau (1933) are often used. Plasma is extracted with $n$-butanol in acid conditions and the extract washed with $4 \mathrm{~N}-\mathrm{NaOH}$ in $5 \%(\mathrm{w} / \mathrm{v}) \mathrm{Na}_{2} \mathrm{CO}_{3}$ (Blau's reagent). Thyroxine stays in the $n$-butanol layer, while di-iodotyrosine and iodide pass into the alkaline washings. This technique is insufficiently specific and would probably not distinguish between different iodothyronines (Roche and Michel, 1955). Moreover, extraction of iodine from blood is not complete and some thyroxine is broken down during the separation.

It seems hardly justifiable, therefore, to use the serum butanol extractable iodine (B.E.I.) for clinical purposes, as recommended by Man, Kydd, and Peters (1951). Man, Bondy, Weeks, and Peters (1954) give a normal range for serum B.E.I. of 3.2 to $6.4 \mu \mathrm{g}$. $/ 100 \mathrm{ml}$. This is, as might be expected, lower than the range accepted for serum P.B.I., 4-8 $\mu \mathrm{g}$. $100 \mathrm{ml}$. (Roche and Michel, 1955).

The only promising fractionation technique for serum iodine is that described by Bowden, Maclagan, and Wilkinson (1955). It gives semiquantitative results but is highly specific and is probably capable of further development to increase its accuracy. One-dimensional chromatograms of $n$-butanol extracts containing iodinated compounds are treated with a ceric sulphatearsenious acid reagent and the degree of decolorization of the yellow ceric ion measured spectrophotometrically in the ultra-violet at intervals along the paper strip. Over the range $0.1-0.3 \mu \mathrm{g}$. of thyroxine (or tri-iodothyronine) 
there is, in the conditions used by Bowden et al. (1955), a linear relation between the galvanometer reading and the amount of amino-acid present. The range over which this relation can be observed is limited by the relative dimensions of the spot and the photocell.

Precautions must be taken to guard against chromatographic artefacts. The chromatographic solvent system, $n$-butanol-dioxane- $2 N$ ammonia ( $4: 1: 5$ by vol.), recommended by Bowden et al. (1955), causes degradation of ${ }^{131}$ I-labelled thyroxine in the tri-iodothyronine and iodide areas unless the dioxane is redistilled to free it from peroxides (Owen, McKenzie, and Orvis, 1956). Moreover, if acidic solvents are used in extraction or chromatography, exchange can occur between iodide and di-iodotyrosine, while free iodine is formed from iodide, which can then iodinate, e.g., unsaturated lipids (Gross and Leblond, 1951; Acland, 1952).

The method of Bowden et al. (1955) requires serum iodine to be concentrated before chromatography. This is best done by extraction with $n$-butanol and subsequent concentration of the extract. This means, however, that the results of the determination will be affected by the incomplete extraction of thyroxine mentioned above. It is, further, not known whether the $n$-butanol-soluble, albumin-like serum iodine component of Robbins, Rall, and Rawson (1955) is detectable on chromatograms by the ceric sulphate-arsenious acid reagent. Two main lines of improvement seem possible. First, an extraction method might be developed which would extract all the thyroxine-like iodine. This would remove one of the main sources of error. Secondly, a refinement of the spectrophotometric technique might increase the degree of correspondence between the galvanometer reading and the amount of iodinated compound present. It might be better to apply the extract to the paper along a starting line instead of to a point and to use a scanner fitted with a slit, similar to the commercial models designed for use with electrophoretograms. A "profile" curve of the chromatogram strip could then be constructed as for serum proteins, by plotting the galvanometer deflection against the distance along the chromatogram. The scanner could be calibrated for the serum iodine components, provided that the area under a segment of the curve were proportional to the amount of iodinated compound contained in the corresponding spot.

Ideally, it might be hoped that a routine method for fractionating serum iodine could be based on the technique of Tong et al. (1952), in which un- treated serum is chromatographed directly. However, the amounts of thyroxine iodine so added are about a hundred times too small to be estimated by the method' of Bowden et al. (1955) nor can they be readily detected on the paper by radiochemical techniques unless the subject has received a dose of radio-iodine in the millicurie range. Doses of this size are given only for therapeutic purposes. Even with the column chromatography technique of Gross and Pitt-Rivers (1952), which, incidentally, also uses $n$-butanol extracts as starting material, radioactivity measurements from patients given tracer doses of a few microcuries present considerable difficulties.

At the present time the problems posed by serum iodine strain both radio-isotope and chemical techniques to their limit. The ultimate goal is a determination of the specific activity of each fraction of serum iodine isolated chromatographically. Only in this way can the function of the thyroid be adequately assessed. Rough specific activity measurements are in theory possible at the moment using rather large doses of radio-iodine and rather large serum samples. It is probable that with the development of scintillation counting and improvement in the chemical determination of Bowden et al. (1955) sufficient accuracy will be attained to make such estimations worth while. However, it would probably not be practicable to carry out this investigation as a routine on all patients suffering from thyroid disease, since the measurements are likely to remain too laborious to permit a large number of determinations to be made simultaneously.

\section{Serum P.B.I. and Assessment of Thyroid Function}

Thyroid function can be assessed at three different physiological levels. First, the rate of hormone production can be estimated by means of radio-iodine tests. Secondly, the concentration of circulating thyroid hormone with which the tissues are in contact can be estimated by means of serum P.B.I. determinations. Thirdly, the reaction of the tissues themselves to the thyroid can be assessed clinically and by means of laboratory tests such as measurements of the basal metabolic rate or the blood cholesterol. In about $90 \%$ of cases of hyper- and hypothyroidism it is found that the results of all tests are in agreement.

The level of serum P.B.I. represents a metabolic equilibrium between synthesis and breakdown of $\mathbb{D}$ thyroid hormone superimposed upon the physico- $\frac{O}{\Phi}$ chemical equilibrium between thyroid hormone in the serum, where it is bound to protein, and in the tissues. 
In most cases the serum P.B.I. concentration in $\mu \mathrm{g}$./1. (B) is a good measure of the rate of hormone supply in $\mu \mathrm{g}$./day $(\mathrm{H})$ and is related to it by the rather simple equation (Riggs, 1952) $B^{2}=34.1 \mathrm{H}$. This equation was derived by a combination of theoretical and empirical calculations and was found to be obeyed rather closely in studies on hypothyroid and euthyroid subjects who had been given thyroid by mouth. The relation assumes a constant clearance rate of hormone from the extrathyroidal body compartment (measured in litres cleared $/ \mathrm{hr} . / \mu \mathrm{g}$. hormonal $I$ in the compartment) and a constant volume of distribution of hormonal iodine relative to the plasma hormonal iodine concentration. These assumptions are not necessarily correct in all situations. An increased clearance rate may occur in adolescence or exposure to cold, thereby leading to an underestimate of hormone production, while a decreased clearance rate may occur in old age leading to a corresponding overestimate. On the other hand, where the concentration of plasma protein is low, as in nephrosis, the volume of distribution of organic iodine in the extrathyroidal compartment relative to the serum P.B.I. concentration may be increased. This could result from an increase in the proportion of unbound thyroxine in plasma when the concentration of thyroxine-binding protein is lowered. In this case, the serum P.B.I. will underestimate the rate of hormone production.

The range within which determinations of serum P.B.I. fall in the case of euthyroid individuals depends on the method used. It is probable that, with the best techniques, most normal values will be found to lie between 4 and $8 \mu$ g. P.B.I./ $100 \mathrm{ml}$. serum, as stated by Roche and Michel (1955). Values below or above these limits are usually obtained in thyroid diseases. There are reasons, however, for suspecting that the upper limit of normal should be set higher than $8 \mu \mathrm{g}$. P.B.I. $/ 100 \mathrm{ml}$. In the case of a method of P.B.I. determination such as that of Barker et al. (1951), which is probably subject to systematic and sporadic losses (Acland, 1957), both limits of the euthyroid range may be lower, certain sera from hyperthyroid patients may appear in the euthyroid range, and some sera from euthyroid patients may appear in the hypothyroid range. This is quite apart from the overlap which would be expected between the serum P.B.I. concentration ranges in normal and pathological conditions. The results of several groups of workers reporting normal ranges of 3 to 7.5 or $8 \mu \mathrm{g}$. $\mathrm{I} / 100 \mathrm{ml}$. may be open to criticism on these lines (e.g., Walser, Ludwig, and Ortelli, 1954 ; Sunderman and Sunderman, 1954 ; Lamberg, Wahlberg, and Forsius, 1956).

The interpretation of a serum P.B.I. determination in a patient is not always straightforward, since, in the first place, the analysis itself is subject to interference by artefacts and, secondly, P.B.I. concentrations outside the normal range are found in some physiological and pathological conditions in which thyroid disease is absent.

Artefactual elevation of serum P.B.I. results from iodide administration in the form of Lugol's iodine, cough mixtures containing potassium iodide, vitamin capsules, etc. This effect persists for a period of days. Serum P.B.I. values remain raised for months or even years after the administration of contrast media for radiography. Raised P.B.I. values are recorded in hyperthyroidism of all types, including cases of acute diffuse (granulomatous) thyroiditis (Owen and McConahey, 1956) and Hashimoto's thyroiditis in the acute phase. Ingestion of a daily dose equivalent to at least $0.2-0.6 \mathrm{~g}$. of thyroid extract is necessary to raise the serum P.B.I. concentration of euthyroid subjects above normal limits (Chamovitz, Sleisenger, and Freedberg, 1951 ; Danowski, Huff, Tarail, Wirth, Peters, Mateer, and Garver, 1952).

In physiological conditions P.B.I. levels, high in comparison with the normal adult range, are found in children (Durham, Cooke, Lancaster, and Man, 1954 ; De Pascale, 1956). Values above $10 \mu \mathrm{g}$. of P.B.I. $/ 100 \mathrm{ml}$. of serum may be observed in the first month of life, a gradual decrease occurring with increasing age until values fall within the normal adult range at about 7 years of age. At puberty the serum P.B.I. level rises slightly before returning to its normal adult level. High values are also obtained in normal pregnancy. By the sixteenth week the serum P.B.I. concentration often rises above the normal limits for adults without evidence of thyrotoxicosis (Heinemann, Johnson, and Man, 1948; Man, Heinemann, Johnson, Leary, and Peters, 1951; Lum and Man, 1955). Failure of the serum P.B.I. to rise during pregnancy is regarded by Lum and Man (1955) as a good indication for thyroid medication to prevent abortion.

A raised serum P.B.I. has been reported in the early stages of acute hepatitis (Kydd and Man, 1951). Cattaneo, De Simoni, and Fantoli (1955) found raised serum P.B.I. levels in patients suffering from pulmonary tuberculosis and observed a further rise after surgical intervention. This last finding is surprising since Engstrom and Markardt (1955) could not detect any effect of surgical stress on serum P.B.I. in patients who were not suffering 
from a concurrent infection. Bonati, Salvi, Rancati, and Pedrelli (1955) have found that a temporary rise in serum P.B.I. follows insulin coma therapy in psychiatric patients.

Artefactual depression of serum P.B.I. may result from the administration of mercurial diuretics since mercury salts interfere with the distillation of iodine and with the chemical determination of iodides by the catalytic method. A 24-hr. interval between medication and taking the blood sample is usually sufficient to allow for elimination of mercury from the blood stream (Barker, personal communication, 1955).

Lowered serum P.B.I. levels are found in hypothyroidism of all types, including Hashimoto's disease in its later stages, familial goitrous cretinism (McGirr and Hutchison, 1953; Stanbury et al., 1955), and hypothyroidism following subtotal thyroidectomy or radio-iodine therapy. Usually a low serum P.B. ${ }^{127} \mathrm{I}$. is associated with a low serum P.B. ${ }^{13}{ }^{1} \mathrm{I}$. and a decreased thyroid uptake of ${ }^{131} \mathrm{I}$. However, in the case of familial goitrous cretins with low serum ${ }^{127} I$ the 48 -hr. serum P.B. ${ }^{131} \mathrm{I}$. is often raised and the thyroid uptake is above normal two and a half hours after administration of ${ }^{131} \mathrm{I}$, although the $24-\mathrm{hr} .{ }^{131} \mathrm{I}$ uptake is normal. Patients rendered hypothyroid by surgery may have a raised thyroid uptake and a high 48-hr. serum P.B. ${ }^{131} \mathrm{I}$. level, although the serum P.B. ${ }^{127} \mathrm{I}$. is low (Blom and Terpstra, 1953), and the same may be true of patients rendered hypothyroid by radio-iodine (Blomfield et al., 1951). These anomalous results arise because the surviving thyroid tissue is incorporating iodine more rapidly into the hormone it secretes than the normal thyroid gland does, and this process is reflected in the P.B. ${ }^{13}{ }^{1} I$. level. However, the actual rate of hormone secretion, on which the P.B. ${ }^{127} \mathrm{I}$. level depends, is low since there is less than the normal amount of active tissue present as a result of therapy or of the disease process.

Cortisone administration may cause a fall in serum P.B. ${ }^{127}$ I., together with lowered values for the B.M.R. and ${ }^{131}$ I tests (Hill, Reiss, Forsham, and Thorn, 1950). Lowered values may also be found in cirrhosis of the liver, sometimes associated with increased thyroid uptake of ${ }^{131} \mathrm{I}$ (Kydd and Man, 1951 ; Mueller, Brausch, Hirsch, Benua, and Dobyns, 1954). These findings probably result from the low plasma protein level in such cases. Debilitating diseases, such as pneumonia, carcinomatosis, malnutrition, terminal heart failure, haemochromatosis, renal failure, gangrene, and fractured femur, cause a lowering of serum P.B.I. (Engstrom and Markardt, 1955).
Bonati et al. (1955) find that the serum P.B.I. level falls in psychiatric patients treated for 10 days with chlorpromazine and phenobarbital. Beierwaltes (1956) has reported a lowered serum P.B.I. together with a raised B.M.R. after administration of dinitrophenol.

Normal serum P.B.I. levels are observed in certain metabolic disorders, which finding may be of diagnostic importance. Patients with large goitres may show an increased thyroid ${ }^{13}{ }^{1}$ I uptake as a result of the large size of the gland, but, unless they are thyrotoxic, will not show an elevated serum P.B. ${ }^{127}$ I. An increased basal metabolic rate with a normal serum P.B.I. may be observed in early congestive heart failure, leukaemia, phaeochromocytoma, acromegaly, essential hypertension, and osteitis deformans (see Bréant, 1955 ; Beierwaltes, 1956). The distinction from thyrotoxicosis thus rendered possible is especially important in cardiac disease. A decreased B.M.R., together with a normal P.B.I., may be found in Addison's disease, hypopituitarism, and anorexia nervosa (see Bréant, 1955). Neither schizophrenia nor affective psychoses appear to be associated with changes in serum P.B.I. concentration (Bonati et al., 1955).

As mentioned above, serum P.B.I. determinations measure only the state of the equilibrium between hormone synthesis and breakdown which is, however, largely determined by the rate of synthesis. Measurements of serum P.B. ${ }^{131} \mathrm{I}$. measure the rate of incorporation of radio-iodine into the circulating thyroid hormone. A combination of the two to yield specific activity measurements would therefore afford a measure of the functional size of the thyroid gland. Although serum P.B.I. determinations by themselves usually correlate well with clinical state (Sunderman and Sunderman, 1954), they are probably most valuable when combined with other tests of thyroid function, including radio-iodine tests and B.M.R. determination, in order to obtain a complete picture of thyroid activity (Fraser, 1956). Methods of determining serum P.B.I. are now available which are sufficiently accurate and reliable for use in a routine chemical pathology laboratory.

\section{Summary}

The nature and determination of blood iodine are reviewed critically. The clinical use of serum P.B.I. determinations is discussed. It is concluded that serum P.B.I. determinations can usefully be performed in a routine laboratory.

I wish to thank Prof. G. M. Wilson, Dr. Arthur Jordan, and Dr. R. Kilpatrick for their comments on 
and interest in this work, and the Board of Governors of the United Sheffield Hospitals for financial assistance.

\section{A P P E N D I X}

\section{P.B.I. by Alkaline Incineration}

The method given below is essentially that previously described (Acland, 1957) with certain modifications introduced as a result of its application to routine estimations (Kilpatrick, 1957). The latter worker found in 20 batches of determinations no significant changes in the calibration curve from batch to batch and no significant difference between duplicate determinations on samples from the same serum analysed in different batches.

Technical Precautions.-Elementary iodine must be excluded from the room where analyses are being carried out and must not be used to sterilize the skin before taking a blood sample. When not in use, glassware is kept immersed in an aqueous solution of an alkaline detergent: "dymex "(Thomas Hedley and Co., Ltd., Newcastle upon Tyne) and "teepol" (British Drug Houses Ltd.) have both been found satisfactory. Immediately before use the glassware is first rinsed thoroughly with tap water, test-tubes being cleaned with a brush, and then washed three times with water purified as described below. Pipettes are dried with acetone on a filter pump, other glassware in a hot air oven at $90^{\circ}$. Containers for blood collection must be kept separate from those used for other laboratory investigations. Scrupulous cleanliness is essential.

Reagents.-All chemicals are AnalaR grade except $\mathrm{HCl}, \mathrm{H}_{2} \mathrm{SO}_{4}$ (" microanalytical reagent," Hopkin and Williams Ltd.), and ceric ammonium sulphate (" laboratory reagent low in other rare earths," British Drug Houses Ltd.). All water is purified by distillation from a metal still and passage through two columns of Amberlite Monobed MB-1 ion-exchange resin. The second resin treatment was given immediately before use.

The KI reference solution contains $130.8 \mathrm{mg}$. of the desiccator-dried salt $/ 1$. ( $\equiv 100 \mu \mathrm{g}$. of $\mathrm{I} / \mathrm{ml}$.). The ceric ammonium sulphate solution contains $19.5 \mathrm{~g}$. of salt in 1 litre of $3.5 \mathrm{~N} \mathrm{H}_{2} \mathrm{SO}_{4}$. The use of this lower concentration brings the extinction readings below 1.0 . The ceric ammonium sulphate solution may deteriorate after a few months (Kilpatrick, 1957). To guard against this, at the beginning of every week add $0.5 \mathrm{ml}$. of the ceric ammonium sulphate solution to $5.5 \mathrm{ml}$. of water, contained in a test-tube, incubate at $37^{\circ}$ for about $20 \mathrm{~min}$. to allow the colour change to proceed to completion, and read $E_{1 \mathrm{em}}$. at $415 \mathrm{~m} \mu$. This procedure has been found to give an extinction reading of 1.4, but other laboratories may obtain different values. The precise value observed is unimportant as long as it remains constant from week to week.

Arsenious acid is prepared by dissolving $3.8 \mathrm{~g}$. of $\mathrm{As}_{2} \mathrm{O}_{3}$ in $50 \mathrm{ml}$. of warm $\mathrm{N}-\mathrm{NaOH}$. To the cooled solution is added $50 \mathrm{ml}$. of water and $3.5 \mathrm{~N} \mathrm{H}_{2} \mathrm{SO}_{4}$ to $500 \mathrm{ml}$.

Precipitation of P.B.I.-Pipette two $1 \mathrm{ml}$. portions of serum into $16 \mathrm{~mm} . \times 125 \mathrm{~mm}$. "pyrex" tubes. Add to each tube $1 \mathrm{ml}$. of water, followed by $1 \mathrm{ml}$. of $100 \%(\mathrm{w} / \mathrm{v}) \mathrm{ZnSO}_{4} .10 \mathrm{H}_{2} \mathrm{O}$ and $1 \mathrm{ml}$. of $0.5 \mathrm{~N} \mathrm{NaOH}$, stirring with a glass rod between each addition. Stand for $3 \mathrm{hr}$. and separate the precipitates by centrifugation at 2,000 r.p.m. for $10 \mathrm{~min}$. Wash the precipitates three times by resuspension in successive $10 \mathrm{ml}$. portions of water, centrifuging and discarding the washing. Suspend each washed precipitate in $1 \mathrm{ml}$. of $4 \mathrm{~N} \mathrm{Na}_{2} \mathrm{CO}_{3}$ by stirring with a glass rod and wash the last traces of precipitate into each tube by adding $0.5-1 \mathrm{ml}$. of water down the rod.

Ashing.-Dry the precipitates overnight at $95-98^{\circ}$. Place the tubes containing dried precipitate in a muffle furnace for three and a half hours at $600^{\circ}$, leaving the furnace door slightly open (about $\frac{1}{4}$ in.) to create a draught. Discard the "pyrex" tubes after they have been used three times.

Estimation of Released Iodine.-Allow the tubes to cool, then add carefully to each residue $1 \mathrm{ml}$. of 2N HCl and mix with a glass rod. Add to each tube $6 \mathrm{ml}$. of water and allow the contents of the tube to stand for half an hour. During this time stir the contents of the tubes three times with a glass rod. Transfer the suspensions to conical centrifuge tubes and separate off the carbonized residues by centrifuging for $20 \mathrm{~min}$. at 3,000 r.p.m.

Pipette a $3 \mathrm{ml}$. sample of each supernatant into a thin-walled $16 \mathrm{~mm} . \times 150 \mathrm{~mm}$. "pyrex" test-tube. Add to each tube $1 \mathrm{ml}$. of water, $0.5 \mathrm{ml}$. of arsenious acid solution, and $1 \mathrm{ml}$. of $3.5 \mathrm{~N} \mathrm{H}_{2} \mathrm{SO}_{4}$ in that order and mix the contents. Place the tubes in a water-bath at $37 \pm 0.1^{\circ}$ and after $10 \mathrm{~min}$. add to each tube $0.5 \mathrm{ml}$. of ceric ammonium sulphate solution at $37^{\circ}$, mix quickly and replace in the bath. The following is a satisfactory method of mixing the contents of the tubes: hold the tube just below its rim in the left hand and flick the bottom of the tube in quick succession with the four fingers of the right hand, repeating this movement about 15 times. Some practice is, however, necessary in order to get good results.

Exactly $12.5 \mathrm{~min}$. after the addition of the ceric ammonium sulphate was begun, measure the extinction of the solution in each tube at $415 \mathrm{~m} \mu$. in a $1 \mathrm{~cm}$. cuvette. Filling of the cuvette is started $45 \mathrm{sec}$. before this time. It is necessary to use a spectrophotometer such as the SP 600 (Unicam Instruments Ltd., Cambridge) equipped with a monochromator. Filter photometers are unsatisfactory. Read the amount of " added iodide," i.e., iodide present in excess of that contaminating the reagents, from a calibration curve, correcting $E_{1} \mathrm{~cm}$. at $415 \mathrm{~m} \mu$. with $\mu \mathrm{g}$. of " added iodide," whose derivation is described below. Multiply the figure thus obtained by $700 / 3$ to give the result in $\mu \mathrm{g}$. of $1 / 100 \mathrm{ml}$. of serum.

It has been found convenient to allow $1 \mathrm{~min}$. between successive additions of ceric ammonium sulphate. This enables six duplicate determinations to 
be carried out in one batch. Two such batches can be conveniently dealt with in one two-day period, comprising in all 11 sera estimated in duplicate and two reagent blanks.

Reagent Blanks.-Run two reagent blanks with each day's group of estimations, one reagent blank per batch. Carry out the entire analytical procedure with $1 \mathrm{ml}$. of water replacing the $1 \mathrm{ml}$. serum sample. The reagents sometimes take up small amounts of iodine on keeping.

Construction of the Calibration Curve.-To tubes containing $3 \mathrm{ml}$. of the eluate from a reagent blank, add in place of $1 \mathrm{ml}$. of water $1 \mathrm{ml}$. samples of solutions containing respectively $0.02,0.04,0.06,0.08$, and $0.10 \mu \mathrm{g}$. of $\mathrm{I}^{\prime} / \mathrm{ml}$.; a reagent blank containing no added iodide provides the zero point. Prepare the tubes for each iodide concentration in two batches of 12. Proceed with the addition of arsenious acid and ceric ammonium sulphate as described above. Plot the mean value of $E_{1} \mathrm{~cm}$. on semilogarithmic graph paper against $\mu \mathrm{g}$. of added iodide and draw a straight line curve to express the relation between them. Construct a fresh curve whenever a fresh solution of any reagent is made up.

\section{REFERENCES}

Acland, J. D. (1952). Nature (Lond.), 170, 32.

Acland, (1957). Biochem, J.,66, 177.

Barker, S. B. (1948). J.biol. Chem., 173, 715.

Humphrey, M. H., and Soley, M. H. (1951), J. clin. Invest., $30,55$.

Beierwaltes, W. H. (1956). Ann. intern. Med., 44, 40.

Blackburn, C. M., and Power, M. H. (1955). J. clin. Endocr., 15, 1379.

Blau, N. F. (1933). J. biol. Chem., 102, 269.

Blom, P. S., and Terpstra, J. (1953). J. clin. Endocr., 13, 989.

Blomfield, G. W., Jones, J. C., Macgregor, A. G., Miller, H., and

- Wayne, E. J. (1951), Brit. med. J., $2,373$.

Bonati, B.,Salvi, A., Rancati, G. B., and Pedrelli, M. (1955). Folia endocr. (Pisa), $8,321$.

Bowden, C. H., Maclagan, N. F., and Wilkinson, J. H. (1955). Biochem. J., $59,93$.

Bréant, P. (1955). Sem. Hôp. Paris, 31, 3160.

Brown, H., Reingold, A. M., and Samson, M. (1953). J. clin. Endocr., $13,444$.

Caraway, W. T. (1952). Ibid., 12, 1215.

Cattaneo, C., De Simoni, G., and Fantoli, U. (1955). Progr. med. (Napoli), 16, 481

Chamovitz, D. L., Sleisenger, M. H., and Freedberg, A. S. (1951). Amer. J. Med., 11, 255.

Chaney, A. L. (1940). Industr. Engng Chem. Anal. Ed., 12, 179.

Crispell, K. R. and Coleman, J. (1956). J. clin. Invest., 35, 475.

Crispell, K. R., and and Hyer, H. (1956). Ibid., 35, 121.

Danowski, T. S., Huff, S. J., Tarail, R., Wirth, P., Peters, J. H. Mateer, F. M., and Garver, K. (1952). J. clin. Endocr., 12, 1572.

Deiss, W. P., Albright, E. C., and Larson, F. C. (1953). Proc. Soc. exp. Biol. (N.Y.), 84, 513 .

De Pascale, A. (1956). Lattante, 27, 84.

Dingledine, W. S. Pitt-Rivers, R., and Stanbury, J. B. (1955). J. clin. Endocr., 15, 724.

Dobyns, B. M.'(1956). Personal communication,
- and Hirsch, E. Z. (1956). J. clin. Endocr., 16, 153.

Durham, J. R., Cooke, R. E., Lancaster, J. W., and Man, E. B. (1954). Amer. J. Dis. Child., 87, 468.

Engstrom, W. W., and Markardt, B. (1955). J. clin. Endocr., 15, 953.

Feller, D. D., Chaikoff, I. L., Taurog, A., and Jones, H. B. (1949) Endocrinology, 45, 464.

Fink, R. M., Dent., C. E., and Fink, K. (1947). Nature (Lond.), 160, 801.

Fischl, J. (1956). Clin. Chim. Acta, 1, 462.

Fraser, R. (1956). Lancet, 2, 581.

Friis, T. (1955). Scand. J. Lab. clin. Invest. 7, 336.

Glasstone, S. (1948). Textbook of Physical Chemistry, 2nd (British) ed., pp. 1087, 1141. Macmillan, London.

Gordon, A. H., Gross, J., O'Connor, D., and Pitt-Rivers, R. (1952). Nature (Lond.), 169, 19.

Gottschalk, C. W., and Riggs, D. S. (1952). J. clin. Endocr., 12, 235

Gottschalk, C. W., and Riggs, (1951). Endocrinology, 48, 714.

Gross, J., and Leblond, C. P. (1951). Endocrino.

Grossmann, A., and Grossmann, G. F. (1955). J. clin. Endocr., 15, 354.
Hamolsky, M. W. (1955). J. clin. Invest., 34, 914.

Harington, C. R., and Randall, S. S. (1929). Biochem. J. 23, 373.

Heinemann, M., Johnson, C. E., and Man, E. B. (1948). J. clin. Invest., 27, 91.

Hill, S. R., Reiss, R. S., Forsham, P. H., and Thorn, G. W. (1950). J. clin. Endocr., 10, 1375.

Ingbar, S. H., Freinkel, N., Hoeprich, P. D., and Athens, J. W. (1954). J. clin. Invest., 33, 388.

Joliot, F., Courrier, R., Horeau, A., and Sïe, P. (1944). C.R. Soc. Biol.'(Paris), 138, 325.

Kilpatrick, R. (1957). Personal communication.

Klein, E. (1954). Biochem. Z., 326, 9.

Kydd, D. M., and Man, E. B. (1951). J. clin. Invest., 30, 874.

Lamberg, B.-A., Wahlberg, P., and Forsius, P. I. (1956). Acta med. scand., 154, 201.

Larson, F. C., Deiss, W. P., and Albright, E. C. (1954). J. clin. Invest., 33, 230.

Leland, J. P., and Foster, G. L. (1932). J.biol. Chem., 95, 165.

Lerman, J. (1940). J. clin. Invest., 19, 555.

Lum, J., and Man, E. B. (1955). Yale J. Biol. Med., 28, 105.

McGirr, E. M., and Hutchison, J. H. (1953). Lancet, 1, 1117.

Man, E. B., Bondy, P. K., Weeks, E. A., and Peters, J. P. (1954). Yale J. Biol. Med., 27, 90.

Heinemann, M. Johnson, C. E., Leary, D. C., and Peters, J. P. (1951). J. clin. Invest., 30, 137.

Kydd, D. M., and Peters, J. P. (1951). Ibid., 30, 531.

- Smirnow, A. E., Gildea, E. F., and Peters, J. P. (1942). Ibid., 21, 773 .

Meyer, K. R., Dickenman, R. C., White, E. G., and Zak, B. (1955), Amer. J. clin. Path., 25, 1160.

Michel, R. (1956). Ann. Rev. Physiol., 18, 457.

Mueller. R. Brausch, C. C. Hirsch, E.Z., Benua, R. S., and Dobyns, B. M. (1954). J. clin. Endocr., 14, 1287.

O'Neal, L. W., and Simms, E. S. (1953). Amer. J. clin. Path., 23, 493. Owen, C. A., and McConahey, W. M. (1956). J.clin. Endocr.,16, 1570 - McKenzie, B. E., and Orvis, A. L. (1956). J. Lab. clin. Med., 47,145 .

Petermann, M. L. Robbins, J., and Hamilton, M. G. (1954). J. biol. Med., 208, 369.

Querido, A., Stanbury, J. B., Kassenaar, A. A. H., and Meijer, J. W. A. (1956). J. clin. Endocr., 16, 1096.

Reals, W. J., Townsend, F. M., and Danielson, R. E. (1956). U.S. Armed Forces med. J., 7, 1293.

Riggs, D. S. (1952). Pharmacol. Rev., 4, 284.

and Man E. B. (1940). J. biol. Chem., 134, 193.

Robbins, J. (1954). J. biol. Chem., 208, 377.

Robbins, J. (1954). J. biol. Chem., 208, 377.). Ibid., 208, 387 Petermann, M. L., and Rall, J. E. (1955). Ibid., 212, 403.

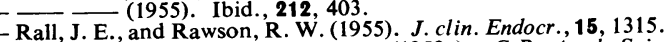

Roche, J., Lissitzky, S., and Michel, R. (1952a). C.R. Acad. Sci., Paris, 234, 997.

Pari, 234, (1952b). C.R. Acad.Sci. (Paris), 234, 1228.

and Michel, R. (1955). Physiol. Rev., 35, 583.

Michel, O., and Lissitzky, S. (1952). Biochim. biophys. Acta, 9,161 .

_- Nunez, J., and Wolf, W. (1955). Ibid., 18, 149.

- Nunez, J., (1956). Ibid., 19, 308 .

Sandell, E. B. and Kolthoff, I. M. (1937). Mikrochim. Acta, 1, 9.

Sanz, M. C., Brechbühler, T., and Green, I. J. (1956). Clin. Chim. Acta $, 1,570$.

Skanse, B., and Hedenskog, I. (1955). Scand. J. Lab. clin. Invest., 7, 291.

Slade, C. I. (1956). J. clin. Endocr., 16, 1122.

Sobel, H., and Sapsin, S. (1952). Anal. Chem., 24, 1829.

Stanbury, J. B., Kassenaar, A. A. H., Meijer, J. W. A., and Terpstra, J. (1955). J. clin. Endocr., 15, 1216.

Meijer, J. W A and Kassenaar A. A. H. (1956). Ibid., 16, 848.

- Brownell, G. L., Riggs, D. S., Perinetti, H., Itoiz, G., and Del Castillo, E. B. (1954). Endemic Goiter. The Adaptation of Man Castillo, E. B. (1954). Endemic Goiter. The Adaptation of Man to Iodine Deficiency, p. 23. Harvard Univ. Press, Cambridge, Mass.

Starr, P., and Liebhold-Schueck, R. (1953). Arch. intern. Med., 92, 880 .

Sunderman, F. W., and Sunderman, F. W., Jr. (1954). Amer. J. clin. Path., 24, 885.

Tata, J. R. (1954). Métabolisme des hormones thy

Thesis. Paris. Quo Rall, J. E., and Rawson, R. W. (1956). J.

Taul, J. E., and Rawsocr, 16, 1554

Taurog, A., and Chaikoff, 176, 639. Wheat, J. D., and Chaikoff, I. L. (1956). Endocrinology, 58, 121.

Thompson, H. L., Klugerman, M. R., and Truemper, J. (1956). J. Lab. clin. Med., 47, 149 .

Tong, W. Taurog, A., and Chaikoff, I. L. (1952). J. biol. Chem., 195, 407.

Trevorrow, (1954). Ibid., 207, 59.

Trevorrow, V. (1939). Ibid., 127, 737. v. (1954). Helv. med. Acta, 21, 413.

Zyl, A. van (1953). S. Afr. J. med. Sci., 18, 61. 